\title{
MONTE CARLO SIMULATION OF MEASUREMENT UNCERTAINTY IN MODIFIED HYDRAULIC BULGING DETERMINATION OF FLOW STRESS
}

\author{
Petar Piljek, Biserka Runje, Zdenka Keran, Marko Škunca
}

Original scientific paper

In this paper an estimation of measurement uncertainty in determining the flow stress curve by modified hydraulic bulging was carried out. Modified hydraulic bulging is a newer method of the stress-strain diagram acquisition. The method has been derived from the hydraulic bulge test. The flow stressstrain curves were established for an aluminium sheet on an experimental apparatus designed for both methods. The assumption of the membrane stress state was used and the flow rule was determined, which was necessary for establishing the flow stress-true strain curve. The comparison between the experimentally obtained curve and standard true stress - true strain curve from literature is showed on a diagram. The estimation of measurement uncertainty was performed using the Monte Carlo simulation.

Keywords: flow stress curve; measurement uncertainty; modified hydraulic bulging; Monte Carlo simulation

\section{Monte Carlo simulacija u procjeni mjerne nesigurnosti krivulje plastičnog tečenja dobivene modificiranim hidrauličkim udubljivanjem}

Izvorni znanstveni članak

U radu je provedena procjena mjerne nesigurnosti rezultata mjerenja korištenih za određivanja krivulje plastičnog tečenja u postupku modificiranog hidrauličnog udubljivanja. Postupak modificiranog hidrauličnog udubljivanja je novo razvijena metoda koja služi za snimanje krivulje plastičnog tečenja materijala, a temelji se na klasičnom postupku hidrauličnog udubljivanja. Na eksperimentalnom postavu pomoću kojeg je moguće provesti oba navedena postupka snimljena je krivulja plastičnog tečenja aluminija. Pretpostavljeno je membransko stanje naprezanja materijala te je izveden uvjet plastičnog tečenja materijala koji je neophodan za snimanje krivulje plastičnog tečenja. Eksperimentalno dobivena krivulja plastičnog tečenja uspoređena je sa standardiziranom krivuljom plastičnog tečenja. Procjena mjerne nesigurnosti provedena je primjenom Monte Carlo simulacije.

Ključne riječi: krivulja plastičnog tečenja; mjerna nesigurnost; modificirano hidraulično udubljivanje; Monte Carlo simulacija

\section{Introduction}

By the definition flow stress curve yields unique and nonlinear relation between true stress and true strain in material. Since both strain and stress are tensors, their degradation to scalars, besides the analytical exactness of this transformation [1], introduces an error to the flow stress curve. The result of this is a great dissipation of curves for the same material when curve acquisition is performed through different methods. Therefore authors $[2,3,4]$ inaugurate the use of hydraulic bulging in recording of the true stress - true strain curve.

From the experimental work of [5] and analytical work of [2] hydraulic bulging was constantly developing $[6,7]$, but has never attained the popularity of standard acquisition methods of true stress - strain curves [3]. Reason to this is dependency of the true stress upon geometrical assumptions set on bulge geometry. Some authors have conducted detailed research on geometry of the bulge and thickness distribution [3, 7] putting the emphasis on strain determination.

Kinematics of modified hydraulic bulging imposes on the implementation of a hypothesis stating that equivalent strain in every point of the body can be defined by measuring only the change in sheet thickness [8,9]. According to that, Hill's hypothesis [10] of equality of circular and meridional deformation in points $O$ and $K$ will be accepted, while in the point of maximal thinning $E$ it will be supposed that circular deformation i.e. strain is equal to zero $\left(\varphi_{c}=0\right)$. Of course, in every point of the deforming sheet the incompressibility assumption is valid. The only, but essential, difference between the classical and the modified hydraulic bulging is in the sphere positioned above the deforming blank, as shown in Fig. 1.
Deforming pressure $p$ "pushes" the sheet onto the sphere with a force $F$ that is produced by a force transducer positioned in the axis of symmetry above the sphere.

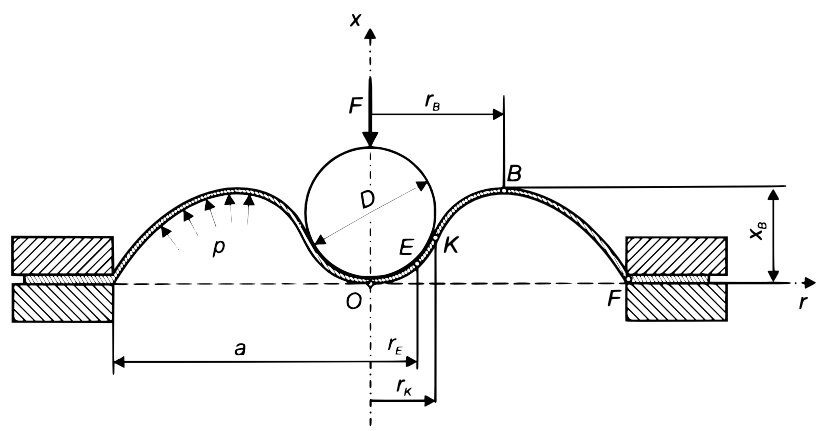

Figure 1Schematic diagram of modified hydraulic bulging [8]

In the procedure of measuring the equivalent stress and thickness strain there are numerous factors that significantly influence the uncertainty of measurement. The main sources of uncertainty that contribute to the uncertainty of measurement results are listed as follows:

- measuring instrument used in the measurement procedure,

- the standard for instrument fine tuning,

- the repeatability and reproducibility of the instrument positioning,

- the geometry of the surface of the measured object (curvature of the surface, out of flatness, surface roughness etc.),

- temperature influence.

Generally, the uncertainty is calculated for a very specific measurement procedure. The specificity of the measuring procedure and the factors of influence must be 
unambiguously defined before the determination of uncertainty.

\section{Stress in modified bulging \\ 2.1 Stress at point $K$}

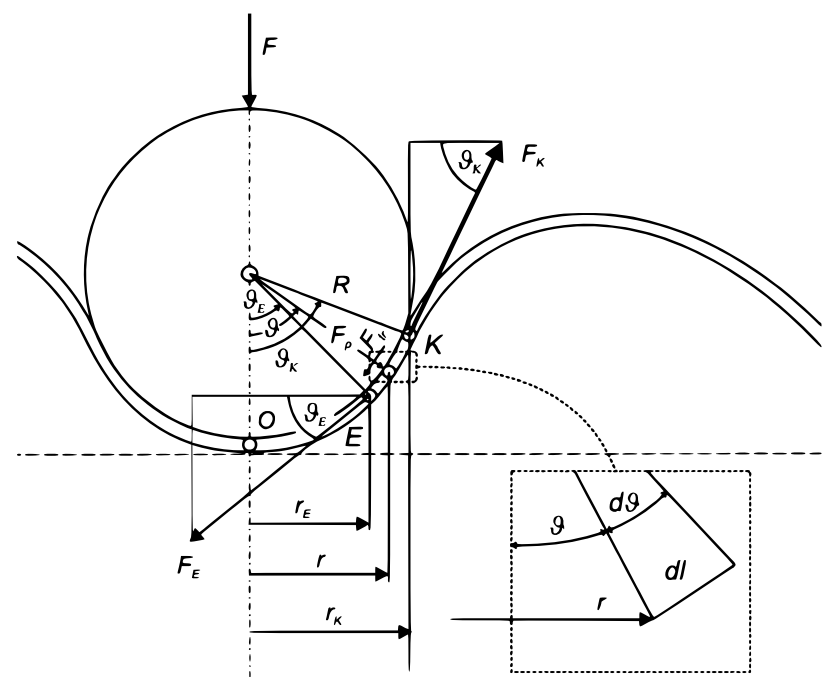

Figure 2 Detailed diagram of forces and geometry in the calculation of stress at point $E[8]$

From the geometry of the deformed blank, diameter $D_{\mathrm{K}}$, angle $\vartheta_{\mathrm{K}}$, shown in Fig. 2, and the sheet thickness at point $\mathrm{K}$, true meridional stress $\sigma_{\mathrm{m}, \mathrm{K}}$ can be calculated at point $\mathrm{K}$ as

$$
\sigma_{\mathrm{m}, \mathrm{K}}=\frac{F_{\mathrm{K}}}{A_{\mathrm{K}}}=\frac{F}{A_{\mathrm{K}} \sin \vartheta_{\mathrm{K}}}=\frac{2 R \cdot F}{\pi \cdot s_{\mathrm{K}} \cdot D_{\mathrm{K}}^{2} \cdot\left(1+\frac{s_{\mathrm{K}}}{2 R}\right)}, \mathrm{MPa}
$$

Here, $F_{\mathrm{K}}=$ force in direction of the normal at point $\mathrm{K}$, $A_{\mathrm{K}}=$ area of normal cross-section of the sheet at point $\mathrm{K}$, $F=$ the force produced by the transducer, $\vartheta_{\mathrm{K}}=$ angle between the axis of symmetry and the normal at point $\mathrm{K}$, $R=$ radius of the sphere, $s_{\mathrm{K}}=$ sheet thickness at point $\mathrm{K}$ and $D_{\mathrm{K}}=$ diameter at point $\mathrm{K}$ (Fig. 2). Since point K lies on the sphere, the radial and the meridional curvature are the same, and consequently circular stress $\sigma_{\mathrm{c}, \mathrm{K}}$ can be calculated from well-known membrane or Laplace equation as

$\sigma_{c, K}=\frac{p_{K}}{s_{K}} R-\sigma_{m, K}, \mathrm{MPa}$

where $s_{\mathrm{K}}=$ thickness at point $\mathrm{K}, R=$ radius of the sphere and $p_{\mathrm{K}}=$ pressure at point $\mathrm{K}$ calculated as

$p_{\mathrm{K}}=p_{\mathrm{CNT}}-p=\frac{4 F}{D_{\mathrm{K}}^{2} \pi}-p, \mathrm{MPa}$

Here $p_{\mathrm{CNT}}=$ contact pressure between sheet and the sphere at point $\mathrm{K}$ and $p=$ deforming pressure.

The required true stress is equal to equivalent von Mises stress. At point $\mathrm{K}$, equivalent von Mises stress, $\sigma_{\mathrm{ekv}, \mathrm{K}}$, is calculated from the meridional, circular and the normal stress as follows

$$
\begin{aligned}
\sigma_{\mathrm{ekv}, \mathrm{K}}= & \left\{\frac { 1 } { 2 } \left[\left(\sigma_{\mathrm{m}, \mathrm{K}}-\sigma_{\mathrm{c}, \mathrm{K}}\right)^{2}+\left(\sigma_{\mathrm{m}, \mathrm{K}}-\sigma_{\mathrm{n}, \mathrm{K}}\right)^{2}+\right.\right. \\
& \left.\left.+\left(\sigma_{\mathrm{c}, \mathrm{K}}-\sigma_{\mathrm{n}, \mathrm{K}}\right)^{2}\right]\right\}, \mathrm{MPa}
\end{aligned}
$$

where $\sigma_{\mathrm{n}, \mathrm{K}}=$ normal stress at point $\mathrm{K}$, which is calculated as a mean value of contact pressure $p_{\mathrm{CNT}}$ and deforming pressure $p$ :

$\sigma_{\mathrm{n}, \mathrm{K}}=-\frac{1}{2}\left(p_{\mathrm{CNT}}+p\right) . \mathrm{MPa}$

\subsection{Stress at point $E$}

Point $\mathrm{E}$ is the point of maximal thinning of the sheet in modified bulging. Therefore, the equilibrium of forces in radial direction $r$ between points $\mathrm{K}$ and $\mathrm{E}$ gives

$\sum F_{\mathrm{r}}=0, \mathrm{~N}$

$-F_{\mathrm{E}} \cos \left(\vartheta_{\mathrm{E}}\right)-F_{\mathrm{tr}} \cos (\vartheta)+F_{\mathrm{p}} \sin (\vartheta)+F_{\mathrm{K}} \cos \left(\vartheta_{\mathrm{K}}\right)=0$

resulting in the force at point E calculated as:

$$
\begin{aligned}
F_{\mathrm{E}}= & \frac{1}{\cos \vartheta_{\mathrm{E}}}\left\{F_{\mathrm{K}} \cos \vartheta_{\mathrm{K}}-p_{\mathrm{K}} R^{2} \pi \mu\left[\cos \left(2 \vartheta_{\mathrm{K}}\right)-\cos \left(2 \vartheta_{\mathrm{E}}\right)\right]+\right. \\
& \left.+2 p_{\mathrm{K}} R^{2} \pi\left\{\left[\vartheta_{\mathrm{K}}-\frac{1}{2} \sin \left(2 \vartheta_{\mathrm{K}}\right)\right]-\left[\vartheta_{\mathrm{E}}-\frac{1}{2} \sin \left(2 \vartheta_{\mathrm{E}}\right)\right]\right\}\right\}, \mathrm{N}
\end{aligned}
$$

Friction factor was taken to be $\mu=0,2$. The meridional force divided by the area of normal cross section of sheet $A_{\mathrm{E}}$ at point $\mathrm{E}$ is equal to stress:

$\sigma_{\mathrm{m}, \mathrm{E}}=\frac{F_{\mathrm{E}}}{A_{\mathrm{E}}}=\frac{F_{\mathrm{E}}}{\pi \cdot s_{\mathrm{E}} \cdot D_{\mathrm{E}}\left(1+\frac{s_{\mathrm{E}}}{2 R}\right)}, \mathrm{MPa}$

Point E lies on the sphere, and consequently the radial and the meridional curvature are the same and the circular stress is calculated from membrane equation as:

$\sigma_{\mathrm{c}, \mathrm{E}}=\frac{p_{\mathrm{K}}}{s_{\mathrm{E}}} R-\sigma_{\mathrm{m}, \mathrm{E}}, \mathrm{MPa}$

where $p_{\mathrm{K}}$ is pressure in point $\mathrm{E}$ which is the same as pressure in point $\mathrm{K}$.

Normal stress at point $\mathrm{E}$ is the same as normal stress at point $\mathrm{K}$ (see above). According to that, the equivalent stress at point $\mathrm{E}$ is given as:

$$
\begin{aligned}
\sigma_{\mathrm{ekv}, \mathrm{E}}= & \left\{\frac { 1 } { 2 } \left[\left(\sigma_{\mathrm{m}, \mathrm{E}}-\sigma_{\mathrm{c}, \mathrm{E}}\right)^{2}+\left(\sigma_{\mathrm{m}, \mathrm{E}}-\sigma_{\mathrm{n}, \mathrm{E}}\right)^{2}+\right.\right. \\
& \left.\left.+\left(\sigma_{\mathrm{c}, \mathrm{E}}-\sigma_{\mathrm{n}, \mathrm{E}}\right)^{2}\right]\right\}^{\frac{1}{2}}, \mathrm{MPa}
\end{aligned}
$$

\subsection{Stress at point 0}

Using the assumption of equal meridional and circular stress at the pole $\sigma_{\mathrm{m}}=\sigma_{\mathrm{c}}$ (commonly used for the 
stress at the pole in hydraulic bulging $[2,5,6,7])$, known thickness $s_{\mathrm{O}}$ and meridional and circular radius equal to the radius of the sphere $R$, and substituting these into membrane equation it is possible to find the plane stress at point $\mathrm{O}$ as:

$\sigma_{\mathrm{m}, \mathrm{c}, \mathrm{O}}=\frac{p_{\mathrm{K}}}{2 s_{\mathrm{O}}} R, \mathrm{MPa}$

where $p_{\mathrm{K}}$ is the same pressure as given for point $\mathrm{K}$. Normal stress at point $\mathrm{O}$ equals normal stress at point $\mathrm{K}$ as it has been previously calculated. Therefore, the equivalent stress at point $\mathrm{O}$ equals:

$$
\sigma_{\mathrm{ekv}, \mathrm{O}}=\left|\sigma_{\mathrm{m}, \mathrm{c}, \mathrm{O}}-\sigma_{\mathrm{n}, \mathrm{O}}\right|, \mathrm{MPa}
$$

\section{Strain in modified bulging}

In order to record the true stress - strain diagram, the equivalent strain has to be determined for points $\mathrm{K}$, $\mathrm{E}$, and O. In order to simplify the measurements, equivalent strain is determined from thickness strain, i.e. from the normal cross-section at each of the points. Using the strain ratio $\beta=\varphi_{2} / \varphi_{1}\left(\varphi_{1}>\varphi_{2}\right)$ [5], the relation between the equivalent and the thickness strain is given as:

$$
\varphi_{\mathrm{ekv}}=\frac{2}{1+\beta} \sqrt{\frac{1+\beta+\beta^{2}}{3}} \varphi_{3},
$$

Where $\varphi_{3}=\ln \left(s_{0} / s_{1}\right)$ is the thickness strain for points $\mathrm{K}$, E, or O. $s_{0}$ is the initial and $s_{1}$ is the final sheet thickness. The strain ratio $\beta$ in Eq. (14) stands for the logarithmic strains $\beta=\varphi_{2} / \varphi_{1}$, as previously mentioned. For points $\mathrm{K}$ and $\mathrm{O}$ it is assumed that the straining process is proportional, i.e. $\beta=1$. Hence, the equivalent strain at points $\mathrm{K}$ and $\mathrm{O}$ is equal to the thickness strain, which simplifies the measurements.

$$
\varphi_{\mathrm{ekv}, \mathrm{K}, \mathrm{O}}=\varphi_{3}
$$

The same assumption was made for classical hydraulic bulging where strain is measured at the pole.

For point $\mathrm{E}$ as the point of maximal thinning, the assumption of the plane strain was made by giving $\beta=0$. Inserting $\beta=0$ in Eq. (14) results in

$$
\varphi_{\mathrm{ekv}, \mathrm{E}}=\frac{2}{\sqrt{3}} \varphi_{3}
$$

In modified hydraulic bulging with no draw in allowed, the strain ratio $\beta$ can only reach values between 0 (plane strain) and 1 (equal biaxial stretching). Since the values of the function given by Eq. (14) are monotonically decreasing from the value $2 / \sqrt{ } 3 \varphi_{3}$ at $\beta=0$ to the value $\varphi_{3}$ at $\beta=1$, the equivalent strain is always within the interval

$$
\varphi_{\mathrm{ekv}} \in\left[1 \ldots \frac{2}{\sqrt{3}}\right] \varphi_{3}
$$

In the presented case of modified hydraulic bulging on the sphere, two cases of strain were considered:

1 . For points $\mathrm{K}$ and $\mathrm{O}$, equal biaxial stretching $\beta=1$ was assumed.

2. For point E, plane strain $\beta=0$ was assumed.

These assumptions resulted in the true stress-strain curve recorded for a $1 \mathrm{~mm}$ thick Al 99,5 sheet [8], shown in Fig. 3.

\section{Calculating measurement uncertainty}

A measurement result is generally expressed as a single measurand quantity value and a measurement uncertainty. According to the International vocabulary of metrology, measurement uncertainty is defined as a parameter that describes the dispersion of quantity values that could reasonably be attributed to the measurand. The uncertainty of the measurement result reflects the lack of complete knowledge about the value of the measurand. In this paper the measurement uncertainty evaluation has been carried out using the Monte Carlo simulations (MCS method) in accordance with the document JCGM 101:2008. The Monte Carlo simulation (MCS method) is a statistic simulation based on use of random numbers and probability statistics $[9 \div 19]$. In the procedure of the measurement uncertainty estimation, MSC method generates random numbers from the probability density function for every input quantity $x_{i}$ and forms the corresponding value of the output quantity $y$, combining various distributions by which input quantities are defined. The procedure is repeated $M$ times and thus an experimental probability density function of the output quantity is reached. For the level of confidence $P$, estimation of the output quantity $y$, estimated standard deviation, and the coverage interval $\left(y_{\left(\left(\frac{1-P}{2}\right) \cdot M\right)}, y_{\left(\left(\frac{1+P}{2}\right) \cdot M\right)}\right)$ are obtained from the experimental probability density function.

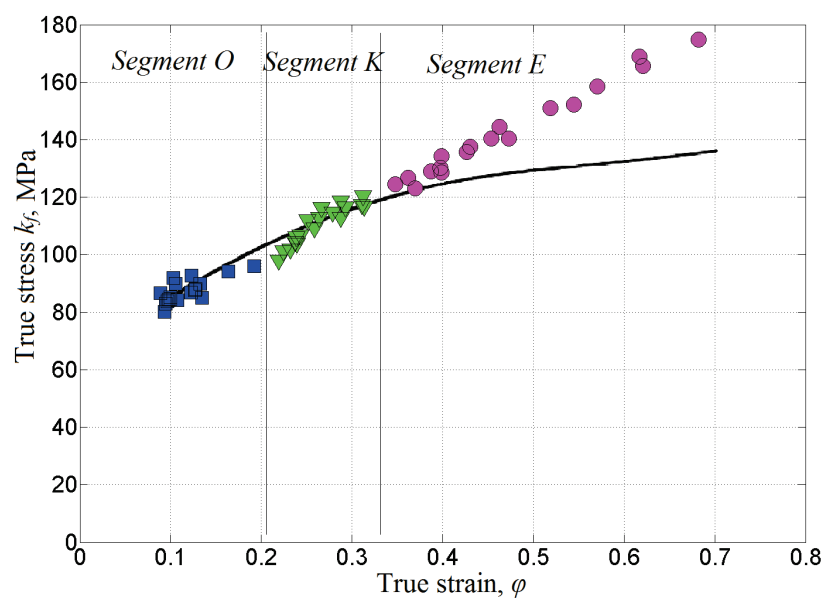

Figure 3 True stress - true strain curve obtained in modified hydraulic bulging experiment compared to true stress - true strain curve from literature [3] 
The probability density functions of equivalent stress and of thickness strain for the $\mathrm{K}, \mathrm{E}$ and $\mathrm{O}$ points, are simulated by the MCS method which is based on Eqs. (1) $\div$ (16). The probability density functions are obtained by the convolution of the input values distribution with $M=$ 100000 simulations.

The input values $x_{i}$ are defined with the probability density functions $g\left(x_{i}\right)$ as shown in Tab. 1 and Tab. 2. The probability density functions of the output values $\sigma_{\mathrm{ekv}, \mathrm{K}}$, $\sigma_{\text {ekv,E }}$ and $\sigma_{\text {ekv, } \mathrm{O}}$ are presented in Fig. $4(\mathrm{a}, \mathrm{b}, \mathrm{c})$. The estimated standard deviations, intervals and expanded uncertainties of the $\sigma_{\mathrm{ekv}, \mathrm{K}}, \sigma_{\mathrm{ekv}, \mathrm{E}}$ and $\sigma_{\mathrm{ekv}, \mathrm{O}}$ values are presented in Tab. 3.The probability density functions of the output values $\varphi_{\mathrm{ekv}, \mathrm{K}}, \varphi_{\mathrm{ekv}, \mathrm{E}}$ and $\varphi_{\mathrm{ekv}, \mathrm{O}}$ are presented in Fig. 5(a, b, c). The estimated standard deviations, coverage intervals and expanded uncertainties of the output values $\varphi_{\mathrm{ekv}, \mathrm{K}}, \varphi_{\mathrm{ekv}, \mathrm{E}}$ and $\varphi_{\mathrm{ekv}, \mathrm{O}}$ are presented in Tab. 4.

Table 1 Input values and probability density functions in simulating of values $\sigma_{\mathrm{ekv}, \mathrm{K}}, \sigma_{\mathrm{ekv}, \mathrm{E}}$ and $\sigma_{\mathrm{ekv}, \mathrm{O}}$

\begin{tabular}{|l|c|l|}
\hline \multicolumn{2}{|c|}{ Input value $x_{i}$} & \multicolumn{1}{|c|}{ Probability density function $g\left(x_{i}\right)$} \\
\hline Deforming pressure at points K, E, O & $p$ & Rectangular distribution $\left(18,838 \times 10^{5} \mathrm{~Pa} ; 19,162 \times 10^{5} \mathrm{~Pa}\right)$ \\
\hline Force at transducer & $F$ & Normal distribution $(6 \mathrm{kN} ; 15 \mathrm{~N})$ \\
\hline Radius of the sphere & $R$ & Normal distribution $(15 \mathrm{~mm} ; 20 \mu \mathrm{m})$ \\
\hline Diameter at point K & $D_{\mathrm{K}}$ & Normal distribution $(29,27 \mathrm{~mm} ; 20 \mu \mathrm{m})$ \\
\hline Diameter at point K & $D_{\mathrm{E}}$ & Normal distribution $(29,71 \mathrm{~mm} ; 20 \mu \mathrm{m})$ \\
\hline Friction coefficient & $\mu$ & Rectangular distribution $(-0,1 ; 0,1)$ \\
\hline Sheet thickness at point K & $s_{\mathrm{K}}$ & Normal distribution $(0,789 \mathrm{~mm} ; 2,5 \mu \mathrm{m})$ \\
\hline Sheet thickness at point E & $s_{\mathrm{E}}$ & Normal distribution $(0,731 \mathrm{~mm} ; 2,5 \mu \mathrm{m})$ \\
\hline Sheet thickness at point O & $s_{\mathrm{O}}$ & Normal distribution $(0,905 \mathrm{~mm} ; 2,5 \mu \mathrm{m})$ \\
\hline
\end{tabular}

Table 2 Input values and probability density functions in simulating of values $\varphi_{\mathrm{ekv}, \mathrm{K}}, \varphi_{\mathrm{ekv}, \mathrm{E}}$ and $\varphi_{\mathrm{ekv}, \mathrm{O}}$

\begin{tabular}{|l|c|l|}
\hline \multicolumn{2}{|c|}{ Input value $x_{i}$} & \multicolumn{1}{|c|}{ Probability density function $g\left(x_{i}\right)$} \\
\hline Initial sheet thickness & $s_{0}$ & Normal distribution $(1,000 \mathrm{~mm} ; 2,5 \mu \mathrm{m})$ \\
\hline Sheet thickness at point K & $s_{\mathrm{K}}$ & Normal distribution $(0,789 \mathrm{~mm} ; 2,5 \mu \mathrm{m})$ \\
\hline Sheet thickness at point E & $s_{\mathrm{E}}$ & Normal distribution $(0,731 \mathrm{~mm} ; 2,5 \mu \mathrm{m})$ \\
\hline Sheet thickness at point O & $s_{\mathrm{O}}$ & Normal distribution $(0,905 \mathrm{~mm} ; 2,5 \mu \mathrm{m})$ \\
\hline
\end{tabular}
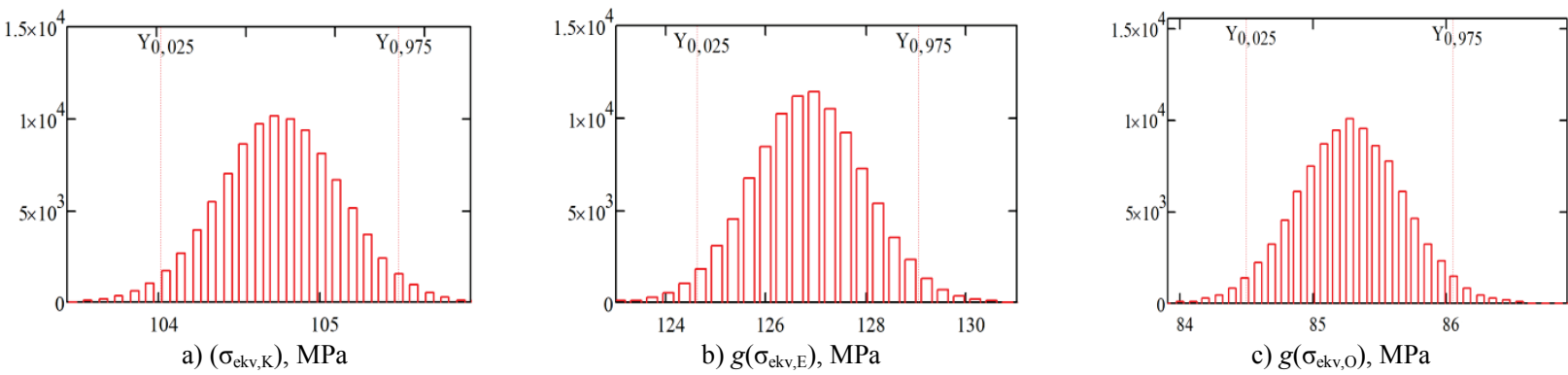

Figure 4 Probability density functions $g\left(\sigma_{\mathrm{ekv}, \mathrm{K}}\right), g\left(\sigma_{\mathrm{ekv}, \mathrm{E}}\right)$ and $g\left(\sigma_{\mathrm{ekv}, \mathrm{O}}\right)$

Table 3 The estimated standard deviations, coverage intervals and expanded uncertainties of the output values $\sigma_{\mathrm{ekv}, \mathrm{K}}, \sigma_{\mathrm{ekv}, \mathrm{E}}$ and $\sigma_{\mathrm{ekv}, \mathrm{O}}$

\begin{tabular}{|c|c|c|c|}
\hline \multirow{2}{*}{ The estimated standard deviation } & $\sigma_{\mathrm{ekv}, \mathrm{K}}$ & $\sigma_{\mathrm{ekv}, \mathrm{E}}$ & $\sigma_{\mathrm{ekv}, \mathrm{O}}$ \\
\hline & $2,0 \mathrm{MPa}$ & $1,12 \mathrm{MPa}$ & $0,4 \mathrm{MPa}$ \\
\hline Interval of the output value & $\begin{array}{c}\left(y_{0,025}=104,03 \mathrm{MPa}\right. \\
\left.y_{0,975}=105,47 \mathrm{MPa}\right) \\
k=2 \\
P=95 \%\end{array}$ & $\begin{array}{c}\left(y_{0,025}=124,65 \mathrm{MPa}\right. \\
\left.y_{0,975}=129,07 \mathrm{MPa}\right) \\
k=2 \\
P=95 \%\end{array}$ & $\begin{array}{c}\left(y_{0,025}=84,49 \mathrm{MPa}\right. \\
\left.y_{0,975}=86,05 \mathrm{MPa}\right) \\
k=2 \\
P=95 \%\end{array}$ \\
\hline Expanded uncertainty & $\begin{array}{c}U=0,7 \mathrm{MPa} \\
k=2 \\
P=95 \%\end{array}$ & $\begin{array}{c}U=2,21 \mathrm{MPa} \\
k=2 \\
P=95 \%\end{array}$ & $\begin{array}{c}U=0,8 \mathrm{MPa} \\
k=2 \\
P=95 \%\end{array}$ \\
\hline
\end{tabular}

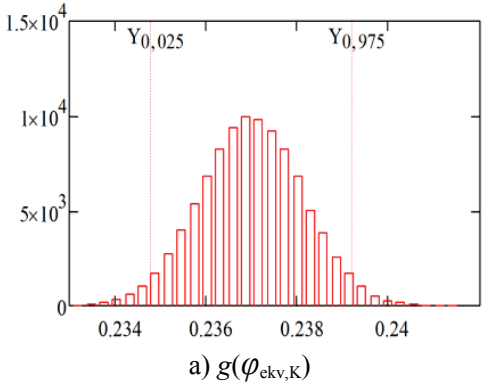

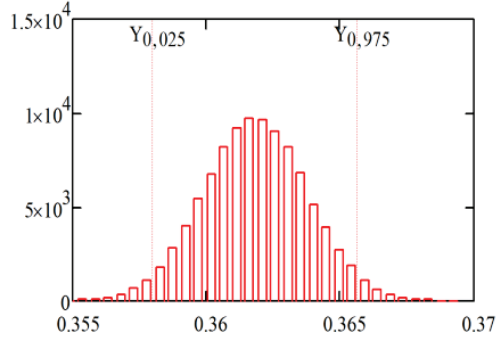

b) $g\left(\varphi_{\text {ekv,E }}\right)$

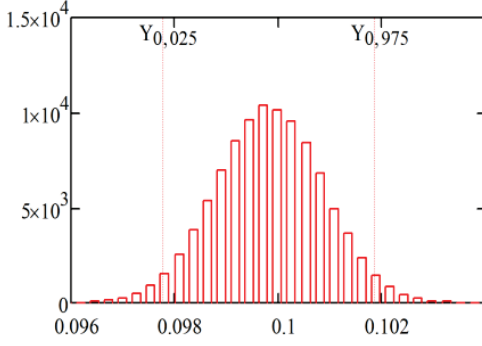

c) $g\left(\varphi_{\mathrm{ekv}, \mathrm{O}}\right)$

Figure 5 Probability density functions $g\left(\varphi_{\mathrm{ck}, \mathrm{K}}\right), g\left(\varphi_{\mathrm{ckv}, \mathrm{E}}\right), g\left(\varphi_{\mathrm{ckv}, \mathrm{O}}\right)$ 
Table 4 The estimated standard deviations, intervals and expanded uncertainties of the output values $\varphi_{\mathrm{ekv}, \mathrm{K}}, \varphi_{\mathrm{ekv}, \mathrm{E}}$ and $\varphi_{\mathrm{ekv}, \mathrm{O}}$

\begin{tabular}{|c|c|c|c|}
\hline \multirow{2}{*}{ The estimated standard deviation } & $\varphi_{\mathrm{ekv}, \mathrm{K}}$ & $\varphi_{\mathrm{ekv}, \mathrm{E}}$ & $\varphi_{\mathrm{ekv}, \mathrm{O}}$ \\
\hline & $1,13 \times 10^{-3}$ & $1,95 \times 10^{-3}$ & $1,04 \times 10^{-3}$ \\
\hline Interval of the output value & $\begin{array}{c}\left(y_{0,025}=0,235, y_{0,975}=0,239\right) \\
k=2 \\
P=95 \%\end{array}$ & $\begin{array}{c}\left(y_{0,025}=0,358, y_{0,975}=0,366\right) \\
k=2 \\
P=95 \%\end{array}$ & $\begin{array}{c}\left(y_{0,025}=0,098, y_{0,975}=0,102\right) \\
k=2 \\
P=95 \%\end{array}$ \\
\hline Expanded uncertainty & $\begin{array}{c}U=2,2 \times 10^{-3} \\
k=2 \\
P=95 \%\end{array}$ & $\begin{array}{c}U=3,8 \times 10^{-3} \\
k=2 \\
P=95 \%\end{array}$ & $\begin{array}{c}U=2 \times 10^{-3} \\
k=2 \\
P=95 \%\end{array}$ \\
\hline
\end{tabular}

\section{Conclusion}

Modified bulging is a new method of stress-strain curve acquisition. For the purpose of testing of the method, only one material, aluminium Al 99,5 was used. In the analysis of the proposed method the membrane state of stress was presumed. Supposition on strain ratio $\beta=0$ at point $\mathrm{E}$ holds only for the ultimate pressures. Experimental results show the difference of $15 \%$ toward stress-strain curve in literature [3]. Since equivalent strain is additive value regarding strain path, further study of modified hydraulic bulging has to consider strain history at point $\mathrm{E}$.

Interesting detail to be considered is a possibility to perform modified hydraulic bulging without a force transducer, using only assumption of the membrane stress at point $\mathrm{B}$. Since there is no thickness stress, exerted force onto the surface of radius $r_{\mathrm{B}}$ by pressure $p$, equals the force $F$ on the sphere, shown in Fig. 1. It is supposed that some standardization of the method in future has to be established.

The relative measurement uncertainties regarding stress is maximum for the segment $\mathrm{E}$ where it is up to 1,8 $\%$ while maximum strain relative measurement uncertainties is obtained for segment $\mathrm{O}$ where it is up to $2,25 \%$. Based on the evaluated measurement uncertainties, it can be concluded that the measurement system is capable of detecting changes in the hydraulic bulging process.

\section{References}

[1] Kachanov, L. M. Fundamentals of the Theory of Plasticity. Mir Publishers, Moscow, 1974.

[2] Hill, R. A theory of plastic bulging of a metal diaphragm by lateral pressure. // Phil. Mag. 41(1950), pp. 1133-1142. DOl: 10.1080/14786445008561154

[3] Doege, E.; Meyer-Nolkemper, H.; Saeed, I. Fliesskurvenatlas metallischer Werkstoffe. Hanser Verlag, München Wien, 1986.

[4] Brown, W. F.; Thompson, F. C. Strength and failure characteristics of metal membranes in circular bulging. // Transactions of ASME. 71(1949), pp. 557-585.

[5] Gleyzal, A. Plastic deformation of circular diaphragm under pressure // Journal of Applied Mechanics. 70(1948), pp. 288-296.

[6] Bell, R.; Duncan, J. L.; Wilson, I. H. A sheet bulging machine with closed loop control. // Journal of Strain Analysis. 2(1967), pp. 246-253. DOI: 10.1243/03093247V023246

[7] Fliesskurven Atlas // Untersuchungen der hydraulischen Tiefung zur Aufnahme von Fliesskurven an Blechwerkstoffen. // Industrie Anzeiger. 90, 38(1968), pp. 775-779.

[8] Škunca, M. Modified hydraulic bulging on the sphere. // $\mathrm{PhD}$ work, University of Zagreb, 2009.
[9] Keran, Z.; Math, M.; Škunca, M. Determination of Flow stress Curve by Modified Hydraulic Bulging. // Transactions of FAMENA. 35(2011), pp. 13-26.

[10] Bendato I.; Cassettari L.; Mosca M.; Mosca R.; Rolando F. New Markets Forecast and Dynamic Production Redesign Through Stochastic Simulation. // International Journal of Simulation Modelling. 14, 3(2015), pp. 485-498. DOl: 10.2507/IJSIMM14(3)10.307

[11] Gusell, A.; Acko, B.; Mudronja, V. Measurement Uncertainty in Calibration of Measurement Surface Plates Flatness. // Strojniski vestnik-Journal of Mechanical Engineering. 55, 5(2009), pp. 286-292.

[12] Madić M.; Radovanović M.; Manić M.; Trajanović M. Optimization of $\mathrm{CO}_{2}$ Laser Cutting Process using Taguchi and Dual Response Surface Methodology. // Tribology in Industry. 36, 3(2014), pp. 236-243.

[13] Primorac, B. B.; Parunov, J. Probabilistic models of reduction in ultimate strength of a damaged ship. // Transactions of FAMENA. 39, 2(2015), pp. 55-74.

[14] Kleiner, M.; Geiger, M.; Klaus, A. Manufacturing of lightweight components by metal forming. // CIRP Annals Manufacturing Technology. 52(2003), pp. 521-542. DOI: 10.1016/S0007-8506(07)60202-9

[15] Ranta-Eskola, A. J. Use of the hydraulic bulge test in biaxial tensile testing. // International Journal Mechanical Sciences. 21(1979), pp. 457-465. DOI: 10.1016/00207403(79)90008-0

[16] JCGM 200:2008 International vocabulary of metrology Basic and general concepts and associated terms (VIM).

[17] JCGM 100:2008 Evaluation of measurement data - Guide to the expression of uncertainty in measurement.

[18] JCGM 101:2008 Evaluation of measurement data Supplement 1 to the "Guide to the expression of uncertainty in measurement" - Propagation of distributions using a Monte Carlo method.

[19] Medić, S.; Kondić, Ž.; Runje, B. Validation of the Realised Measurement Uncertainty in Process of Precise Line Scales Calibration. // Technical Gazette. 19, 2(2012), pp. 331-337.

\section{Authors' addresses}

\section{Petar Piljek, Ph.D. Student}

Department of Technology, Faculty of Mechanical Engineering and Naval Architecture, University of Zagreb, Croatia Ivana Lučića 5, 10002 Zagreb, Croatia

E-mail: petar.piljek@fsb.hr

\section{Prof. Biserka Runje, Ph.D.}

Department of Quality, Faculty of Mechanical Engineering and Naval Architecture, University of Zagreb, Croatia Ivana Lučića 5, 10002 Zagreb, Croatia E-mail: biserka.runje@fsb.hr

\section{Zdenka Keran, Ph.D.}

Department of Technology, Faculty of Mechanical Engineering and Naval Architecture, University of Zagreb, Croatia Ivana Lučića 5, 10002 Zagreb, Croatia

E-mail: zdenka.keran@fsb.hr

\section{Marko Škunca, Ph.D.}

Alstom, Dubrovačka 45, 10312 Predavec

E-mail: skunca.marko@gmail.com 